\title{
Die ontmitologiseringsprogram van Rudolf Bultmann
}

GMM Pelser

\begin{abstract}
Rudolf Bultmann's program of demythologizing

As the heading above indicates, the main purpose of this essay is an endeavour to give an exposition of Bultmann's program of demythologizing. Attention is consecutively given to Bultmann's definition of myth; the problem, according to Bultmann, created for modern man by the mythic worldview of the New Testament and the mythological depiction of the salvation event therein; the impossibility of upholding this view in modern times; the necessity for demythologizing; demythologizing through existential interpretation; results, such as Bultmann's views on speaking about God; the acts of God; God's revelation; the Christ-event and eschatology. The essay is concluded with a short, mainly appreciative evaluation.
\end{abstract}

'n Mens kan sonder vrees vir noemenswaardige teenspraak die stelling maak dat Rudolf Bultmann sedert die twintigerjare van hierdie eeu vir baie dekades en tot vandag toe die mees omstrede figuur op die terrein van die Christelike teologie was. En sou iemand nie saamstem dat dit die geval is wat die teologie in die algemeen betref nie, dan minstens op die gebied van die Nuwe-Testamentiese wetenskap. In teologiese literatuur, wetenskaplik of populêr-wetenskaplik, kom 'n mens male sonder tal sy naam teë en word daar òf instemmend ò afwysend op sy teologiese denke gereageer. Om egter slegs te sê dat hy 'n omstrede figuur was en nog steeds is, is beslis nie voldoende nie. Hieraan moet toegevoeg word dat hoe omstrede ook al, Bultmann sonder twyfel die grootste Nuwe-Testamentikus is wat die twintigste eeu tot dusver opgelewer het.

Dit is in die lig hiervan ' $n$ jammerte dat daar in die Suid-Afrikaanse teologiese konteks, op enkele uitsonderings na, so min kennis geneem is van die fenomenale teologiese nalatenskap van hierdie man. Die ooglopende verklaring hiervoor is gewis dat Bultmann, soos dit trouens in die meeste kringe van die Christelike wêreld die geval was, deur baie beskou is as ' $n$ ketter en ' $n$ ondergrawer van die Christelike geloof. ' $n$ 
Mens moet toegee dat Bultmann met talle insigte en uitsprake vorendag gekom het wat skokkend geklink het en nog klink vir baie teoloë en gelowiges wat hulle teologie en geloof aan die hand van bepaalde tradisionele denkmodelle beoefen het en nou nog beoefen.

'n Baie belangrike rede vir die skok en verontrusting wat deur diesulkes ervaar is, is die feit dat hulle hulle bepaalde tradisionele en met sorg gekoesterde religieusiteit deur hom omvergewerp of bedreig gesien het. Baie van hierdie mense het hom beslis nie verstaan nie en baie het hom tot ketter verklaar op grond van hoorsê, sonder om self die moeite te doen om te lees wat hy te sê gehad het. Bultmann het hom hieroor by geleentheid soos volg uitgelaat:

Es ist unglaublich, wie viele Leute sich ein Urteil über meine Arbeit anmassen, die nie ein Wort von mir gelesen haben .... Ich habe dann gefragt, worauf sich das Urteil des Schreibers gründe, und was er von meinen Schriften gelesen habe. Die Antwort laütete regelmässig, ohne Ausnahme: nichts gelesen von meinen Schriften! Aber aus einem Sonntags- oder Gemeindeblatt erfahren, dass ich ein Irrlehrer sei (aangehaal deur Schmithals 1966: 21).

Hierdie houding teenoor Bultmann word nog tot vandag toe aangetref ten spyte van die feit dat hy male sonder tal die versekering gegee het dat sy intensie nooit was om die Christelike geloof te skaad nie. Dit blyk trouens ook meer as duidelik uit sy geskrifte dat hy as 't ware die Christelike geloof wou red en bevorder deur die Skrif vir die hedendaagse mens te midde van hedendaagse denkmodelle nog steeds relevant te maak. 'n Mens sal ver soek om nog iemand te kry wat met soveel piëteit die Skrif as Anrede van God, geloofwekkend vir die mense van ons tyd wou laat spreek as Bultmann. Maar Bultmann het vroeg reeds ingesien dat die Woord van God, om dit volgens die stelreël van die nuwe-hermeneutici te sê, alleen werklik by sy bedoelde adres kan uitkom en kan tref, as dít wat gesê moet word, dit wil sê dieselfde saak, anders gesê word.

Hiermee word nie voorgegee dat daar geen kritiek op Bultmann te lewer is nie. Daar mag van hom verskil word betreffende die metodes wat deur hom gebruik is, maar oor sy goeie bedoelings kan daar min twyfel bestaan. ' $n$ Mens kan in hierdie opsig kwalik van Schmithals verskil wanneer hy sê:

Um diese Sache, die Sache Jesu Christi, die Sache des Evangeliums, die Sache der Kirche oder wie immer wir formulieren wollen, ist es Bultmann stets gegangen (Schmithals 1966: 2). 
Een van die komponente van Bultmann se teologiese denke en werksaamhede wat seker die grootste reaksie uitgelok het, is sy hermeneutiese program van ontmitologisering en die daarmee onlosmaaklikgepaardgaande eksistensiale interpretasie van die Skrif. 'n Mens hoef maar slegs te kyk na die debat wat oor'n paar dekades heen in verskeie bande van Kerygma und Mythos onder redaksie van HW Bartsch neerslag gevind het, om ' $n$ besef te kry van die wye en lewendige reaksie en belangstelling wat dit uitgelok het. Dan praat ons nie eens van die menigte publikasies wêreldwyd, waarin ook deur die jare heen hierop gereageer is nie - en die laaste woord is nog lank nie gespreek nie.

\section{BRONNE}

Oor die probleem van die mite, veral in die Nuwe Testament, het Bultmann vir die eerste keer in 1936 gehandel in 'n opstel getitel 'Jesus und Paulus' (Bultmann 1967: 210-229). Die term ontmitologisering en wat hy daarmee beoog, kom die eerste keer aan die orde in ' $n$ voordrag getitel 'Neues Testament und Mythologie', wat hy op 21 April 1941 te Frankfurt am Main voor predikante van die 'Bekennende Kirche' gelewer het. Hierdie voordrag is in dieselfde jaar gepubliseer in die tydskrif Beiträge zur Theologie waarin die werk van die verbode tydskrif Evangelische Theologie voortgesit is (kyk Schelkle 1985: 257). Op hierdie opstel het nog 'n paar ander gevolg waarin Bultmann uitsluitlik sy denke oor ontmitologisering uiteengesit het, naamlik 'Zum Problem der Entmythologisierung' (1952a); 'Zur Frage der Entmythologisierung: Antwort an Karl Jaspers' (1954); 'Jesus Christus und die Mythologie' (1965a); en nogmaals 'Zum Problem der Entmythologisierung' (1965b). Benewens hierdie opstelle het Bultmann natuurlik in baie van sy werke nie alleen die prinsipes vir ontmitologisering op een of ander wyse weer aan die orde gestel nie, maar ook sy ontmitologiseringsprogram as hermeneutiese metode konsekwent in sy interpretasie van die Skrif deurgevoer. Vir ons doel, naamlik om te probeer uitmaak wat hierdie ontmitologiseringsprogram alles behels, sal ek my egter in hoofsaak bepaal by die hierbo genoemde opstelle.

\section{DIE PROBLEEM}

Ons het gemerk dat in twee van die hierbo genoemde opstelle die woord 'Problem' gebruik is. Waarna verwys dit? Enersyds verwys dit 
volgens my mening na die probleem wat Bultmann met sy ontmitologiseringsprogram op teologiese terrein laat ontstaan het. Andersyds verwys dit egter, wat Bultmann betref, na wat hy met betrekking tot die Skrif, en in die besonder die Nuwe Testament, as die probleem beskou waarmee die eksegeet in die moderne wêreld gekonfronteer word. Hierdie probleem is naamlik die mitiese denkwyse wat in die Nuwe Testament tot uitdrukking kom en wat volgens Bultmann eenvoudig nie meer in die twintigste eeu gehandhaaf kan word nie. So begin hy dan ook sy voordrag in 1941 met die eerste sub-opskrif 'Das Problem' waaronder hy tuisbring 'Das mythische Weltbild und das mythische Heilsgeschehen im Neuen Testament' en 'Die Unmöglichkeit der Repristinierung des mythischen Weltbildes' (Bultmann 1948: 15v).

\subsection{Wat is mite en mitologie?}

Alvorens ons die vraag stel oor wat Bultmann as mities in die Nuwe Testament beskou, is dit eers nodig om uit te mak wat Bultmann onder mite en mitologie verstaan. "Ich verstehe unter "Mythos" ein ganz bestimmtes geschichtliches Phänomen und unter "Mythologie" eine ganz bestimmte Denkweise' (Bultmann 1952a: 180). Bultmann wys verder daarop dat hy die begrip mite gebruik soos dit in die Godsdienswetenskap verstaan word. 'Mythos ist der Bericht von einem Geschehen oder Ereignis, in dem übernatürliche, übermenschliche Kräfte oder Personen wirksam sind (daher oft einfach als Göttergeschichte definiert). Mythisches denken ist der Gegenbegriff zum wissenschaftlichen Denken' (Bultmann 1952a: 180). Die mitiese denke skryf bepaalde fenomene of gebeurtenisse aan bonatuurlike, aan goddelike magte toe, of hulle ook al dinamisties of animisties of as persoonlike geeste of gode voorgestel word of nie. So word bepaalde fenomene en gebeurtenisse, maar ook gebiede afgegrens van die bekend-vertroude, deurskou- en beheersbare entiteite en gebeurtenisse van die wêreld. Die mite 'redet vom Unweltlichen weltlich, von den Göttern menschlich' (Bultmann 1948: 23). Dit praat oor die handelinge van hierdie buitewêreldse magte in taal en terme wat tot die wêreldse werklikheid behoort. Dit praat dus van die handelinge van die gode soos van menslike handelinge, behalwe dat die gode as baie magtiger as mense voorgestel word en dat hulle handelinge as onberekenbaar beskou word en in staat om die natuurlike verloop van sake te deurbreek (Bultmann 1952a: 184). 'Man kan sagen, Mythen geben der transzendenten Wirklichkeit eine immanente weltliche Objektivität. Der Mythe 
objektiviert das Jenseitige zum Diesseitigen' (Bultmann 1965a: 146). Daarmee word die buitewêreldse gevolglik ook geobjektiveer 'zum Verfügbaren, was sich darin zeigt, dass der Kultus mehr und mehr zu einer das Verhalten der Gottheit beeinflussenden, ihren Zorn abwendenden, ihre Gunst gewinnenden Handlung wird' (Bultmann 1952a: 184). Hierdie denkwyse is totaal anders as die wetenskaplike denke wat werk met oorsaak en gevolg. Vir die wetenskaplike denke is dit 'n vereiste dat vir elke uitspraak 'n begronding gegee moet word, terwyl 'n gebrek aan samehang eie is aan mitiese vertellinge. Vir die mitiese denke is die wêreld en wêreldgebeure 'oop' - oop vir die ingrype van buite-wêreldse magte. Vir die wetenskap is die wêreld en wêreldgebeure 'geslote' en alleen oop in soverre die kennis van die wêreld en wêreldgebeure nooit afgesluit is nie.

Oor sy definisie van wat as ' $n$ mite beskou moet word, het Bultmann uit verskeie oorde kritiek ontvang. Daar is geargumenteer dat hy uitgegaan het van 'n te breë definisie van wat ' $n$ mite of van wat mities of mitologies is. Sy benadering dat ' $n$ mite min of meer gelyk is aan wat onhistories, onwerklik, nie-feitelik is, en nie te rym is met die moderne wetenskaplike wêreldbeeld nie, is en word as te simplisties beskou. Daar is daarop gewys dat daar nie alleen verskillende definisies bestaan van wat ' $n$ mite of mities is nie, maar ook dat daar onderskei kan word tussen mites van verskillende aard (kyk byvoorbeeld Dunn 1977: $285 \mathrm{vv}$ ). Bultmann se reaksie hierop was dat hy die vraag na die begrip mite nie as van die gewigtigste beskou nie en dat as iemand onder mite iets anders wil verstaan as hy, dit so 'n persoon vrystaan om so te doen. Hy meen dus dat 'n ander definisie nie aan die saak sal verander nie en nie die probleem sal versag nie. 'Vielmehr scheint mir die Diskussion dieser Frage von dem wegzuführen, um was es eigentlich beim Problem der Entmythologisierung geht' (1952a: 180).

\subsection{Die mitiese wêreldbeeld en die mitiese heilsgebeure in die Nuwe Testament}

In terme van sy beskouing oor wat ' $\mathrm{n}$ mite is, begin Bultmann sy 1941voordrag met die stelling dat die wêreldbeeld van die Nuwe Testament mities is. Die wêreld word gesien as bestaande uit drie afdelings te wete die hemel, die aarde en die onderwêreld. Die hemel is die woonplek van God en die hemelse gestaltes, die engele; die onderwêreld is die hel, die plek van ellende waar die duiwel sy woonplek het. Maar ook die aarde is nie 'n plek van die natuurlik-alledaagse gebeur- 
tenisse nie. Dit is die toneel van die bedrywighede van bonatuurlike magte: God en sy engele, die Satan en sy demone. Hierdie magte gryp in in die natuurlike verloop van sake asook in die denke, wil en handelinge van die mense. Wonders kom dikwels voor. Die mens het nie mag oor homself nie, demone kan van hom besit neem en die satan kan bose gedagtes by hom wek. Maar ook God kan die mens se denke en wil rig, kan hom hemelse gesigte laat sien, hom sy bevelende of vertroostende woord laat hoor en aan hom die bonatuurlike krag van sy Gees skenk. Die geskiedenis loop ook nie sy bestendige, wetmatige gang nie, maar verkry sy beweging en rigting van die bonatuurlike magte. Hierdie aiōn staan onder die mag van die Satan, die sonde en die dood en is vinnig op pad na sy einde toe, 'n nabye einde wat hom as 'n kosmiese katestrofe sal voltrek. Soos wat die weë van die eindtyd voor die deur is, so is ook die koms van die hemelse regter, die opstanding van die dooies en die gerig tot heil of verderf voor die deur (kyk Bultmann 1948: 15).

Ook die wyse waarop die heilsgebeure in die Nuwe Testament beskryf word, stem volkome ooreen met hierdie mitiese wêreldbeeld. In mitologiese taal word verkondig: die eindtyd het gekom; toe die tyd vol geword het, het God sy Seun gestuur. Hierdie preëksistende Godwese het as 'n mens op aarde verskyn. Sy dood aan die kruis wat Hy soos 'n sondaar gesterf het, het versoening vir die sondes van die mense bewerkstellig. Sy opstanding is die begin van die kosmiese katastrofe waardeur die dood wat deur Adam in die wêreld gebring is, tot niet gemaak sal word. Die demoniese wêreldmagte het hulle mag verloor. Die opgestane is tot die regterhand van God in die hemel verhoog en tot Here en Koning gemaak. Hy sal weer kom op die wolke van die hemel om die heilswerk te voltooi. Dan sal die opstanding van die dooies en die gerig plaasvind en sal sonde, dood en alle leed vernietig wees. Dit sal baie gou gebeur, so gou dat Paulus dit nog tydens sy lewe verwag het (kyk Bultmann 1948: 15v).

\subsection{Die onmoontlikheid van die handhawing van hierdie wêreldbeeld}

Om hierdie mitiese wêreldbeeld in die moderne tyd te bly handhaaf en van die hedendaagse mens te verwag om dit te aanvaar, is volgens Bultmann beide sinloos en onmoontlik. Dit is sinloos omdat hierdie wêreldbeeld as sodanig nie spesifiek Christelik is nie, maar eenvoudig die wêreldbeeld is van 'n vergange tyd wat nog nie deur wetenskaplike denke gevorm was nie (Bultmann 1948: 17). Die wêreldbeeld en 
mitologie wat ons in die Nuwe Testament aantref, is oorgeneem uit die Joodse apokaliptiek en die gnostiese verlossingsmite (Bultmann 1948: 28). Beide is van die dualistiese oortuiging dat die wêreld deur demoniese magte beheers word en verlossing nodig het. Die apokaliptiek sien hierdie verlossing bewerkstellig deur die goddelike ingrype wat aan hierdie wêreld ' $n$ einde maak en 'n nuwe daarstel deur sy Messias. Die gnosis verwag die verlossing deur middel van die godseun wat uit die ligwêreld kom en, vermom as mens, deur sy lot en leer diesynes bevry en vir hulle die weg na die hemelse vaderland baan.

Dit is onmoontlik om vandag van mense te verwag om hierdie wêreldbeeld te aanvaar omdat ' $n$ mens eenvoudig nie deur ' $n$ besluit ' $n$ wêreldbeeld kan oorneem nie. Wêreldbeeld is reeds ' $n$ gegewenheid in die historiese situasie waarin die mens hom bevind. Net so is met die moderne denke die kritiek op die Nuwe-Tetamentiese wêreldbeeld 'n gegewenheid. Geen mens kan met erns hierdie wêreldbeeld onderskryf nie. Geen volwasse, hedendaagse mens stel hom meer God daarbo in die hemel voor nie; die hemel in hierdie sin van die woord bestaan vir ons nie meer nie.

Für den Menschen von heute sind das mythologische Weltbild, die Vorstellung vom ende, vom Erlöser und der Erlösung vergangen und erledigt (Bultmann 1965a: 145).

Erledigt sind damit die Geschichten von der Himmel- und Höllenfahrt Christi; erledigt ist die Erwartung des mit den Wolken des Himmels kommenden 'Menschensohnes' und des Entrafftwerdens der Gläubigen in die Luft, ihm entgegen (1 Thess 4, 15ff) (Bultmann 1948: 18).

Dit geld ook die geeste- en demonegeloof, die wonders, die mitiese eskatologie. Kan ons, vra Bultmann, in die lig van die moderne wêreldbeeld, van die hedendaagse mens verwag dat hy 'n sacrificium intellectus moet pleeg deur iets vir waar te moet aanvaar bloot omdat dit in die Bybel staan (Bultmann 1965a: 145)?

Die mens wat die mitiese denke ontgroei het, sien homself as 'n eenheid en skryf sy gevoelens, denke en wil aan homself toe en nie meer aan die ingrype van demoniese of goddelike magte nie. En al is dit so dat sy geestelike lewe nie los van sy liggaamlikheid staan nie, weet hy dat hy sy selfstandigheid as persoon telkens weer moet laat realiseer. Juis om hierdie rede weet hy van sy verantwoordelikheid vir homself en vir sy vryheid. Hy kan homself in sy verhouding tot God ook slegs as 'n persoon sien wat in sy bestaan as persoon deur God aangespreek 
word. God se handelinge kan hy ook alleen waarneem in soverre hy dit eksistensieel ervaar. 'n Satisfaksieleer wat God se handeling as 'n kultiese of juridiese beskryf, 'n Christusgebeure wat nie verstaan kan word as iets wat die persoonlike eksistensie tref nie, is vir hom ongeloofwaardig.

Hierdie mens kan nie elektriese beligting en elektroniese apparaat gebruik, in geval van siekte moderne mediese behandeling ontvang en tegelyk in die geeste- en wonderwêreld van die Nuwe Testament glo nie. Wat die Nuwe Testament van die Gees en die sakrament sê, is vir hom vreemd en onverstaanbaar. Hy kan ook nie insien dat die dood die straf vir die sonde is nie. Die dood is vir hom ' $n$ eenvoudige en noodwendige natuurgebeure. Hy ken skuld slegs as 'n daad waarvoor hy self verantwoordelik is en kan daarom ook nie insien dat sy voorouers verantwoordelik was vir die feit dat hy verdoem sal word nie. Insgelyks kan hy nie insien en verstaan waarom Christus as skuldlose plaasbekledend vir hom moes sterf nie.

Welche primitiven Begriffe von Schuld und Gerechtigkeit liegen solcher Vorstellung zugrunde? Welch primitiver Gottesbegriff? Soll die Auschauung vom sündentilgenden Tode Christi aus der Opfervorstellung verstanden werden: welch primitive Mythologie, dass ein Mensch gewordenes Gottwesen durch sein Blut die Sünden der Menschen sühnt! (Bultmann 1948: 21).

Die moderne mens kan ook nie Jesus se opstanding verstaan as 'n gebeurtenis waarkragtens 'n lewensmag tot stand gekom het wat 'n mens jou alleen deur die sakramente kan toeëien nie. Vir die biologiese denke is so iets totaal sinloos, omdat vir hierdie denke die dood nie as probleem geld nie. Vir die idealis is dit wel sinvol om van 'n lewe te praat wat nie aan die dood onderworpe is nie, maar dat die moontlikheid van so 'n lewe bewerkstellig kan word deur 'n gestorwene wat weer tot die fisiese lewe opgewek word, is vir hom onvoorstelbaar. So is ten slotte ook die voorstelling dat die dood en opstanding van Christus nie 'n geïsoleerde gebeurtenis was nie, maar 'n gebeurtenis met kosmiese implikasie waarby die mens ingetrek is sodat hy uiteindelik in die hemelse ligwêreld verplaas sal word en in ' $n$ hemelse pneumatiese bestaanswyse sal voortbestaan, vir die moderne mens nie alleen rasioneel onvoorstelbaar nie, maar ook niksseggend. 'Denn er versteht nicht, dass in einem solchen Zustand sein Heil bestehen soll, in dem er zur Erfüllung seines Lebens, seiner Eigentlichkeit käme' (Bultmann 1948: 21). 
So onaanvaarbaar as wat die mitiese wêreldbeeld is vir die moderne wetenskaplike denke waarin oorsaak en gevolg grondliggend is, so onaanvaarbaar is dit vir die geskiedwetenskap. Ook nie die moderne geskiedwetenskap hou rekening met die ingryping van God of die duiwel of demone in die gang van sake nie. Dit kan alleen die geloof in God se handelinge as 'n historiese fenomeen waarneem, maar nie God self nie. Dit kan nie weet of hierdie geloof ' $n$ werklikheid weerspieël nie, aangesien so 'n buitewerklikheid nie vir hom bestaan nie. Die loop van die geskiedenis word as 'n ongebroke gebeure beskou, hoewel daarin sekere magte aan die werk is. Niks geskied ook sonder 'n rasionele begronding nie, anders sou daar nie so iets as verantwoordelikheidsin kon bestaan nie. Daar bestaan in die moderne wêreld wel nog bygeloof, maar dit is duidelik 'n abnormaliteit (Bultmann 1965a: 144; 1965b: 133).

\subsection{Die noodsaaklikheid van ontmitologisering}

Wat staan die Christelike teoloog nou te doen, indien Bultmann dit oor hierdie saak reg het? Moet hy eenvoudig die mitiese in die Skrif elimineer en hom alleen bepaal by byvoorbeeld die etiese uitsprake wat daarin voorkom? Beslis nie, antwoord Bultmann (Bultmann 1965a: 146; 1965b: 133). Die mite moet geinterpreteer word na sy eintlike bedoeling. Wat egter wel geëlimineer kan word, is die etiologiese mites wat niks anders is as primitiewe wetenskaplike verklarings van natuurverskynsels nie. Daar moet derhalwe onderskei word of ons met 'n mite te doen het wat slegs verklarend van die wêreld wil praat of met 'n mite wat iets wil sê van die werklikheid van die mens self, dus van sy eksistensie (Bultmann 1965b: 134).

Die eintlike bedoeling van laasgenoemde mite is nie om 'n objektiewe wêreldbeeld te gee nie, al praat die mite oor die nie-wêreldse op objektiverende wyse soos 'n mens van wêreldse fenomene sou praat. Die bedoeling van hierdie mite is in werklikheid om tot uitdrukking te bring hoe die mens homself in sy wêreld verstaan. Om herdie rede wil die mite nie kosmologies nie, maar antropologies, beter nog, eksistensiaal geïnterpreteer word. Die mite hou trouens ook in homself die motief in vir kritiek teen hom. Sy intensie om van 'n transendente mag te praat, word deur die objektiverende karakter van sy uitsprake verhinder en bedek (Bultmann 1948: 23; 1952a: 183). Dit praat dus wel van ' $n$ werklikheid en is die uitdrukking van 'n bepaalde verstaan van hierdie werklikheid, maar dit praat daaroor op ontoereikende wyse 
(Bultmann 1952a: 183). Dit wil oor 'n werklikheid praat wat buite die objektiveerbare, sigbare en beheersbare werklikheid lê, en wel van 'n werklikheid wat vir die mense van beslissende betekenis is. Dit is ' $n$ werklikheid wat vir hulle heil of onheil, genade of toorn kan beteken en van hulle eerbied en gehoorsaamheid eis (Bultmann 1965b: 128).

Die mites in die Skrif moet daarom nie na hulle voorstellingsaard bevra word nie. Hulle sin lê nie in hulle objektiverende denke nie, maar in die Existenzverständnis wat in hierdie voorstellings tot uitdrukking kom (Bultmann 1948: 24, 28; 1952a: 183). Watter Existenzverständnis? Dié dat die mens hom in 'n wêreld bevind wat vol raaisels en geheimenisse is en dat hy ' $n$ lot ervaar wat net so raaiselagtig en geheimenisvol is. $\mathrm{Hy}$ het die gevoel dat hy nie beheer oor sy eie lewe het nie en dat die wêreld en die menslike lewe sy grond en sy grense het in ' $n$ mag buite hierdie berekenbare en beheersbare werklikheid, 'n transendente mag (Bultmann 1952a: 183; 1965b: 134).

Ook die Nuwe Testament self maak kritiek onafwendbaar vanweë die feit dat daarin voorstellings voorkom wat in teenspraak met mekaar is. So staan byvoorbeeld die dood van Christus as offer teenoor sy dood as kosmiese gebeurtenis; Messias teenoor tweede Adam; die kenosis teenoor die wonders; die maagdelike geboorte teenoor die preëksistensie; die skeppingsgeloof teenoor die geloof in magte wat die wêreld beheers; die wet deur God gegee teenoor die wet deur engele gegee.

Kritiek is veral 'n vereiste op grond van 'n eienaardige teenspraak wat dwarsdeur die Nuwe Testament voorkom: die mens is aan die een kant kosmies gedetermineerd, aan die ander kant word hy geroep tot beslissing; enersyds word die sonde as (sy) lot gesien, andersyds as skuld; naas die indikatief staan daar die imperatief. Kortom, enersyds word die mens as kosmiese wese gesien, andersyds as ' $n$ selfstadige ek wat homself deur sy beslissings kan wen of verloor. 'Daher denn auch die Tatsache, dass manche Worte des Neuen Testaments den Menschen von heute ohne weiteres direkt anreden, während andere ihm unverständlich und verschlossen sind' (Bultmann 1948: 24).

Ook die eskatologiese uitsprake van die grootste gedeelte van die Nuwe Testament is mitologies van aard en vereis ' $n$ ontmitologiserende interpretasie. In hierdie opsig is uitsprake op die tydsvlak gemaak nie alleen oor 'n nabye katastrofiese einde van die wêreld nie, maar ook oor die begin van 'n nuwe salige tydperk. Hierdie beskouing oor die eskatologie as 'n kosmiese gebeurtenis aan die einde van die tyd het gespruit uit die algemeen-menslike onsekerheid oor die toekoms. Die eskatologiese prediking het die hede in die lig van die toekoms gesien 
en aan die mense verkondig dat hierdie wêreld, die wêreld van die natuur en die geskiedenis, die wêreld waarin ons leef en ons planne beraam, nie die enigste wêreld is nie, maar dat dit tydelik en verbygaande is, ja leeg en onwerklik in die lig van die ewigheid (Bultmann 1965a:148). Die wêreld het geskyn by sy einde te wees en die krisis, die oordeel van God, baie naby. Terwyl in die Ou Testament die oordeel van God nog oorwegend gesien is as iets wat hom in die volkeregeskiedenis voltrek, het daar in die apokaliptiek 'n ingrypende verandering ingetree. Nou is die oordeel nie meer só gesien nie, maar gesien as 'n supranaturale gebeure wat deur 'n kosmiese katastrofe begelei word en wat die einde van die geskiedenis teweegbring.

Sofern das Ende der Welt das Ende des alten, bösen Äons im Gericht Gottes ist, bricht die Geschichte ab. Ihr Ende wird ihr von Gott gesetzt und ist nicht der organische Schluss, die Vollendung einer Entwicklung (Bultmann 1964: 34).

Hoewel die Ou-Testamentiese geskiedsbeskouing nie volledig in die Nuwe Testament verdwyn het nie, het die apokaliptiese eskatologie beslis die oorheersende geword. Daar bestaan verder geen twyfel daaroor dat Jesus hom by hierdie apokaliptiese siening aangesluit het nie, hoewel sy verkondiging in sekere opsigte anders was. Hierdie eskatologiese verkondiging van Jesus is op sy beurt deur sy gemeente oorgeneem en voortgesit. 'Alles das bedeutet: Im Urchristentum ist die Geschichte von der Eschatologie verschlungen worden' (Bultmann 1964: 42). Die vroeg-Christelike kerk het homself derhalwe nie as 'n historiese nie, maar as 'n eskatologiese fenomeen verstaan. Hy het homself gesien as nie meer behorende tot hierdie wêreld nie, maar tot die komende 'geschichtslosen' aiōn, wat besig was om aan te breek. Die vraag is egter hoe lank hierdie siening kon bly voortbestaan en hoe lank die verwagting van die dreigende wêreldeinde onvernietigbaar kon bly.

Dat dit nie bly voortbestaan het nie, minstens nie oral in die vroegste kerk nie, is reeds in die Nuwe Testament duidelik. 'Bald macht es sich ja geltend, dass die erwartete Parusie des Menschensohnes ausbleibt und bald erwachen Enttäuschung und Zweifel' (Bultmann 1964: 42). Daarom dat gelowiges in sekere gevalle vermaan moes word om nie moeg te word nie, maar geduldig te bly wag (Jak 5: 7vv; Heb 10: 36 ens), en dat uitgesproke twyfel oor die wederkoms beveg moes word (2 Pet 3: 4). Reeds by Paulus het daar' $n$ wending ingetree. Hoewel hy nog bly vashou het aan die ou apokaliptiese toekomsverwagting van die 
wederkoms, die opstanding van die dooies en die groot gerig, het hy dit begin ontmitologiseer deurdat hy die klem verskuif het na die opstanding van Christus as dié beslissende gebeurtenis. Die kerk is vir hom die eskatologiese gemeenskap van die uitverkorenes, die heiliges, wat reeds geregverdig is en lewe. Die Gees wat verwag is as die gawe van die tyd van saligheid, is reeds gegee. Die tyd tussen die opstanding van Christus en sy wederkoms is die interregnum van die Messias (Bultmann 1965a: 155). Johannes egter het nog verder gegaan en die eskatologie radikaal geontmitologiseer. Vir Johannes is die koms en weggaan van Jesus die eskatologiese gebeurtenis. 'Für Johannes sind die Auferstehung Jesu, Pfingsten und die Parusia Jesu ein einziges Ereignis und die Glaubenden haben schon jetzt das ewige Leben' (Bultmann 1965a: 155). 'Für Johannes ist die Totenauferstehung und das Gericht Gegenwart geworden mit dem Kommen Jesu' (Bultmann 1964: 53). Ook Johannes het vooruitgesien na die toekomstige voleinding van die huidige geloofslewe. Anders as Paulus sien hy die voleinding egter nie soos die apokaliptiese eskatologie as 'n kosmiese katastrofe, die opstanding van die dooies en die oordeel oor die wêreld nie. Die voleinding het vir hom betrekking op die toekoms van die individuele gelowige ná die einde van sy aardse lewe. Dit doen hy volgens die voorstellingswyse van die gnostiese eskatologie. 'Die traditionelle Vorstellung von der Parusie ist umgedeutet; Jesus verheisst den Seinen, das er kommen wird, sie zu sich zu holen in eine der zahlreichen himmlischen Wohnungen (Joh 14: 2f.)' (Bultmann 1964: 56). Dit beteken nie dat Johannes die paroesie ontken het nie. 'Vielmehr Johannes öffnet dem Leser die Augen: die Parusie ist schon geschehen' (Bultmann 1958a: 144). Daar bly slegs nog twee moontlikhede oor: om in die lewe te wees of in die dood, in die hemel of in die hel. Die lewe in geloof in die openbaring is om in die hemel te wees, die lewe sonder geloof in die openbaring is voortaan die hel (Bultmann 1958a: 145).

Dit is vir Bultmann vanselfsprekend dat, aangesien daar in die Nuwe Testament self met die ontmitologisering van die apokaliptiese eskatologie begin is, en dit soos in die geval van Johannes selfs radikaal deurgevoer is, ons nie anders kan as om dieselfde te doen nie. Die Naherwartung wat Christus en die vroegste Christene gehad het, is immers ook nie vervul nie. Die wêreld bestaan nog soos voorheen, die geskiedenis het voortgegaan sonder dat die naby verwagte einddrama aangebreek het en die Menseseun op die wolke van die hemel verskyn het. Die verloop van die geskiedenis het dus die mitologie weerlê (Bultmann 1965a: 143; 1964: 44). Bultmann beskou dit derhalwe as 
onvermydelik dat die ergernis (Anstoss) wat die Bybelse wêreldbeeld vir die moderne mens bied, verwyder moet word. Deur dit te doen word die egte ergernis eers vrygestel. Hierdie ergernis bestaan daarin dat God se Woord die mens uit sy angs en uit sy selfgefabriseerde sekerheid roep na God toe en daarmee na sy eintlike eksistensie toe, maar hom ook roep om vry te word van die wêreld wat hy deur sy wetenskaplike denke probeer beheers, en dan op so 'n wyse dat hy daarmee aan die wêreld mag oor homself gee (Bultmann 1952a: 188).

\section{DIE ONTMITOLOGISERINGSPROGRAM}

\subsection{Ontmitologisering as eksistensiale interpretasie}

Uit wat tot dusver gesê is, het dit reeds duidelik geword dat Bultmann van oordeel is dat die mite, soos hy dit verstaan, in essensie niks anders is nie as die uitdrukking van die Existenzverständnis van die mens. Aangesien hierdie Existenzverständnis egter op ontoereikende wyse deur die objektiverende denke en spreke van die mite uitgedruk en juis daarom verberg word, is ontmitologisering as hermeneutiese metode onontbeerlik en gebiedend. Ontmitologisering wil die eintlike intensie van die mite tot gelding bring. Hierdie intensie is naamlik om te praat oor die eksistensie van die mens as begrond en begrens deur 'n buitewêreldse, nie-wêreldse mag, 'n mag wat nie vir die objektiverende denke sigbaar is nie.

Negativ ist die Entmythologisierung daher Kritik am Weltbild des Mythos, sofern dieses die eigentliche Intention des Mythos verbirgt. Positiv ist die Entmythologisierung existentiale Interpretation, indem sie die Intention des Mythos deutlich machen will, eben seine Absicht, von der Existenz des Menschen zu reden (Bultmann 1952a: 184).

Dit is op hierdie punt belangrik om daarop te wys dat die eksistensiale interpretasie nie slegs ' $n$ onderdeel uitmaak van Bultmann se teologiese arbeid nie. Inteendeel, sy teologie voltrek hom in sy geheel as eksistensiale interpretasie (so tereg Schmithals 1966: 271v; Hübner 1985: 645) omdat die Nuwe Testament volgens hom in sy geheel eksistensiale interpretasie vereis. Daar moet verder ook gelet word op die strenge onderskeid wat Bultmann handhaaf tussen die begrippe existential en existentiell. Schmithals (1966: 70v) het Bultmann se denke oor die saak soos volg goed opgesom: Dit is wel so dat indien 'n mens eksistensiaal 
of eksistensieel sê, dit in beide gevalle om eksistensie gaan, maar dan in elke geval om eksistensie in 'n ander opsig. Die eksistensiale analise ontvou die wese van menslike eksistensie as sodanig. Dit analiseer die struktuur van die eksistensie. Dit verklaar begripsmatig wat dit beteken dat die mens, anders as ander natuurwesens, sy eie moontlikheid is. Dit omlyn die verskillende bestaansmoontlikhede, maar is self nie die voltrekking of gebeure van eksistensie nie. Waar die mens egter vir'n konkrete moontlikheid van eksistensie besluit, is hy nie meer in eksistensiale analise begrepe nie, maar eksistensieel betrokke. Die mens kies op grond van sy eksistensiale struktuur telkens in eksistensiële beslissing een van die moontlikhede van sy konkrete Dasein. Hy eksisteer, en eksistensie geskied nie eksistensiaal nie, maar steeds eksistensieel. Hoewel verskeie kritici van Bultmann nie kon insien hoe hierdie onderskeid gehandhaaf kon word nie (kyk bv Hübner 1985: 647v) en Barth selfs daarmee gespot het (vgl Schmithals 1966: 69), het Bultmann by sy standpunt gebly. Dit het in elk geval ook nie vir hom soseer om die term gegaan nie, maar om die metode.

Natürlich kommt es auf den Terminus 'existential' nicht an; wer will oder kann, mag einen besseren finden. Es sollte nur deutlich sein, dass mit der existentialen Interpretation eine Methode der Auslegung, eine die Auslegung leitende Fragestellung, gemeint ist; und es sollte nicht ständig die 'existentiale' Interpretation mit einer existentiellen verwechselt werden (Bultmann 1952a: 184, voetnoot 1).

Vir Bultmann is dit egter vanselfsprekend dat die eksistensiale interpretasie nie die eksistensiële betrekking wat die Skrif op die leser het, daarstel nie; dit onthul slegs hierdie betrekking. Dit begrond ook nie die waarheid van die Skrif nie, maar toon dit slegs aan en leer die leser om dit te verstaan. Dit begrond eweneens nie die verkondiging nie, maar verskaf daarvoor die regte begripsmatigheid. Ten slotte begrond dit ook nie die geloof nie, maar dui aan wat die grond vir die geloof is, terwyl dit die geloof tegelyk daarvan kan bewaar om homself verkeerd te verstaan (Bultmann 1952a: 189).

Dit is algemene kennis watter noue verwantskap daar tussen Bultmann se eksistensiale interpretasie en Heidegger se eksistensiefilosofie te bespeur is. Hoewel dit Bultmann dikwels voor die deur gelê is dat sy teologie deur Heidegger se filosofie beïnloed is en dat hy die interpretasie derhalwe aan die heerskappy van 'n wesensvreemde wetenskap uitgelewer het, het hy dit steeds ontken. Al waarom dit vir hom 
gegaan het, is om die 'regte' filosofie te vind wat die begripsmateriaal kon verskaf waarmee uitdrukking gegee kon word aan die Existenzverständnis wat in die Skrif tot uitdrukking kom. Wat hierdie 'regte' filosofie moet doen, is om die vraag te stel na die sin van eksistensie, nie as eksistensiële vraag nie, maar as eksistensiaal-analitiese vraag na wat eksistensie oor die algemeen beteken, wetende dat die eksistensiële vraag slegs in eksistensie self beantwoord kan word. Dit is verder vir Bultmann ' $n$ onomstrede feit dat elke eksegetiese begripsmatigheid op een of ander wyse van 'n filosofie afhanklik is. Vir hom is dit '. . . eine Illusion, zu meinen, dass je eine Exegese unabhängig von einer profamen Begrifflichkeit getrieben werden kann' (Bultmann 1952a: 192).

Die filosofie wat gevolglik deur Bultmann beskou word as die bruikbaarste vir die verskaffing van die nodige begripsmateriaal vir die gepaste interpretasie van die Skrif, is dié van Heidegger. Hy sien in Heidegger se eksistensiale analise van die Dasein slegs die profane filosofiese daarstelling van die Nuwe-Testamentiese beskouing oor die menslike eksistensie. Hoe sien hierdie filosofie die mens? Dit sien die mens as histories-eksisterend in die besorgdheid oor homself op grond van die angs waarmee hy vervul is. Dit sien hom as iemand wat hom telkens bevind in die oomblik van beslissing tussen die verlede en die toekoms. Hy word gekonfronteer met die vraag of hy homself sal verloor in (aan) die wêreld van wat voorhande is en van ' $n$ mens' sowel as met die vraag of hy sy Eigentlichkeit (sy ware lewe) sal bekom in die prysgawe van alle sekerhede en in die onvoorwaardelike vry wees vir die toekoms. 'Ist nicht so auch im Neuen Testament der Mensch verstanden?', vra Bultmann (1948: 35). Wie in die lig hiervan beswaar maak dat die Nuwe Testament met kategorieë van die eksistensiefilosofie geïnterpreteer word, hou hom, so meen Bultmann, blind vir die probleem wat daar fakties aanwesig is. 'Ich meine man sollte lieber darüber erschrecken, dass die Philosophie von sich aus schon sieht, was das Neue Testament sagt' (Bultmann 1948: 35).

Om van eksistensiaal-filosofiese kategorieë gebruik te maak om die Nuwe Testament te interpreteer, is dus nie 'n uitverkoop van die eksegese aan die filosofie nie. Die vraag is nie of die aard van die mens sonder die Nuwe Testament ontdek sou kon word nie, want fakties is dit nie sonder die Nuwe Testament ontdek nie. Vandag se filosofie kon eenvoudig nie daar wees sonder die Nuwe Testament, Luther en Kierkegaard nie. Daar kan egter nie 'n geesteshistoriese samehang tussen die twee gekonstateer word nie, en dit bewys wel dat die 
Nuwe-Testamentiese geloofsbegrip gesekulariseer kan word en dat die Christelike eksistensie niks misterieus of supranaturaal is nie (Bultmann 1948: 37). Daar is egter tog 'n belangrike verskil. Die filosofie meen dat hy die mens tot vryheid kan bring deur die ware natuurlikheid van die mens vry te stel. Die Nuwe Testament leer daarenteen dat die mens hom nie self van sy wêreldvervallenheid kan losmaak nie. Dit geskied alleen deur 'n daad van God. Die Nuwe Testament verkondig daarom ook nie 'n leer oor die natuur, oor die eintlike wese van die mens nie, maar hierdie vrymakende daad van God. Die Nuwe Testament sien die toestand van die mens sonder Christus as 'n vertwyfelde, terwyl die filosofie dit nie so sien nie. Die filosofie is van oortuiging dat die mens, te midde van sy vervallenheid, nie alleen oor die wete om sy Eigentlichkeit beskik nie, maar ook oor die moontlikheid om dit self te bekom. Die Nuwe Testament sien hom as iemand wat die moontlikheid tot Eigentlichkeit verloor het en wie se wete om Eigentlichkeit daardeur vervals is (Bultmann 1948: 38v).

\subsection{Die mitiese of mitologiese ge-ontmitologiseer}

Wat het Bultmann se ontmitologisering van die mitiese denke en spreekwyse van die Nuwe Testament nou in werklikheid opgelewer? Dit is vanselfsprekend onmoontlik om binne hierdie bestek ' $n$ breedvoerige relaas te gee, en daarom gaan ek my beperk tot ' $n$ paar van die belangrikste resultate van sy program.

\subsubsection{Die spreke 'oor' God}

Bultmann se ontmitologiserende denke word reeds duidelik wanneer hy sy antwoord gee op die vraag na die moontlikheid om van God te praat. Dat die objektiverende spreke oor God in die Skrif nie letterlik geneem kan word nie, berus vir hom daarop dat 'n mens nie oor God kan praat as ' $n$ algemene waarheid nie. Om oor God te praat het geen sin nie, want dit sou beteken dat ek my téénoor God moet stel, my van Hom moet kan losmaak en distansieer vir besinning oor Hom. Dan is God nie meer die Almagtige, die allesbepalende Werklikheid nie, maar het 'n mens Hom tot 'n objek, tot 'n wêreldfenomeen gemaak. Elke objektiewe of neutrale uitspraak oor God is ' $n$ ontkenning van ons eksistensiële bepaald-wees deur God, van ons aangespreek wees deur God. Wanneer 'n mens oor God algemeen-geldende uitsprake maak, plaas jy jou buite die werklikheid van jou eksistensie en daarmee saam buite God. Ons kan alleen uit God van God praat, en hierdie spreke van 
God uit God kan alleen deur God gegee word (Bultmann 1958: 26-28). Hierdie uit God is alleen moontlik op grond van God se openbaring. Maar hierdie openbaring is altyd God se handeling aan ons, die handeling waardeur ons eksistensie bepaal word.

Uit hierdie oortuiging van Bultmann dat ons nie oor God kan praat buite ons eksistensiële 'getroffen'-wees deur God om nie, spruit die nou reeds bekende stelling: 'Es zeigt sich also: will man von Gott reden, so muss man offenbar von sich selbst reden' (Bultmann 1958b: 28; 1958c: 117v). En dit is gevolg deur die ewe bekende stelling in verband met die Pauliniese teologie: 'Jeder Satz über Gott ist zugleich ein Satz über den Menschen und umgekehrt. Deshalb und in diesem Sinne ist die paulinische Theologie zugleich Anthropologie' (Bultmann 1968: 192). Hoewel met betrekking tot die Pauliniese teologie gesê, kan hierdie stelling inderdaad beskou word as Bultmann se prinsipiële denke oor die vraag na teologie, die vraag na hoe van God gepraat kan word. In lyn hiermee beskou hy dan ook die vraag na God, die vraag na God se openbaring, as die vraag na die waarheid van die menslike eksistensie (Bultmann 1952b: 233). Die mens sou God ook nooit deur sy openbaring kon leer ken as daar nie in elke mens ' $n$ 'existentielle Wissen um Gott' aanwesig was nie. In die menslike bestaan is hierdie 'existentielle Wissen um Gott' aanwesig as die vraag na geluk, na heil, na die sin van die wêreld en die geskiedenis, as die vraag na die 'Eigentlichkeit des je eigenen Seins' (Bultmann 1952b: 232).

Die indruk mag ontstaan dat dit alles daarop neerkom dat God nie buite die geloof om bestaan nie, dat God dus as ' $t$ ware alleen bestaan in soverre daar in Hom geglo word. Hierdie afleiding word deur Bultmann ten sterkste afgewys.

Aus dem Satz, dass nur der Glaube, der sich von Gott getroffen weiss, von Gott reden kann, dass also der Glaubende, wenn er von Gottes Handeln redet, eben damit auch von sich selbst redet, folgt keineswegs, dass Gott nicht ausserhalb des Glaubenden, bzw. des Glaubensaktes, wirklich sei ... (Bultmann 1952a: 198).

\subsubsection{Die spreke oor God se handelinge}

As dit alleen moontlik is om op hierdie wyse van God te praat, hoe moet of kan daar dan oor die handelinge van God gedink en gepraat word? Aangesien God geen objektief-vasstelbare wêreldfenomeen is nie, kan daar van sy handelinge slegs so gepraat word dat daar tegelyk gepraat word van ons eksistensie wat deur sy handelinge geraak is. Maar net so moet daaraan vasgehou word dat ons geraak-wees deur God se hande- 
linge 'n gebeure is wat nie vasstelbaar, nie aanwysbaar is nie. Hierdie geraak-wees geskied in 'n konkrete situasie en dit is vanselfsprekend dat die persoon wat geraak is, hierdie situasie ook na die handeling van God sal terugvoer. En dit is legitiem solank dit net nie in objektiverende sin as kousaal gesien word nie. Hier kan gepraat word van 'n wonder, nie van 'n mirakel nie (Bultmann 1952a: 196; 1965b: 135).

Die geloof praat, soos met betrekking tot die wonder in die lewe van die gelowige, ook van God se handelinge as van sy skeppers- en heersersbeskikking in natuur en geskiedenis, en so moet dit ook. Net soos die gelowige sy lewe sien as deur God bepaal, so sien hy God se hand ook werksaam in die natuur en geskiedenis waarbinne sy lewe afspeel. Maar hierdie wete kan slegs as 'n belydenis uitgespreek word en nie as 'n algemene waarheid soos 'n natuurwetenskaplike of geskiedsfilosofiese teorie nie. In so 'n geval sou God se handelinge as 'n wêreldse gebeurtenis geobjektiveer word. 'n Uitspraak oor God se skeppers- en heersershandeling het sy legitieme grondslag slegs in die eksistensiële selfverstaan van die mens (Bultmann 1965b: 135).

God handel inderdaad in die wêreld en die geskiedenis. Hy handel egter nie tussen die wêreldgebeurtenisse nie, maar daarin (Bultmann 1952a: 196; 1965a: 173). Dit beteken dat God nie ingryp in die gang van sake in die natuur of geskiedenis nie, maar dat $\mathrm{Hy}$ wel in hierdie gebeurtenisse (kan) handel. Hierdie handelinge van God is egter slegs vir die geloofsoog sigbaar. Buite die geloof om is dit nie sigbaar of bewysbaar nie. 'n Gebeurtenis wat op die oog af na 'n doodgewone gebeurtenis lyk, mag later herken word as iets waarin die hand van God gewerk het (Bultmann 1964: 174). Dit gaan hier egter nie om 'n direkte identiteit tussen die wêreldgebeure en die handelinge van God soos by die panteïsme nie, maar om 'n paradokse identiteit. Kyk ons na die wêreldgebeure as 'n geslote samehang, en ons moet ook so daarna kyk vir ons daaglikse arbeidslewe, dan is daarin geen ruimte vir God se handelinge nie. 'Aber eben das ist das Paradox des Glaubens, dass er ein in seinem natürlichen und geschichtlichen Zusammenhang feststellbare Ereignis gleichwohl als Gottes Tat versteht' (1952a: 198).

Bewus daarvan dat dit om wêreldgebeurtenisse gaan, glo die geloof tog nog dat God daarin handel. Hierdie tog nog is nie van die geloof los te maak nie. So 'n geloof alleen is egter geloof in wonders (Bultmann 1952a: 198). In die geloof ontken ons die geslote samehang van wêreldgebeurtenisse, die ketting van oorsaak en gevolg, maar ons doen dit nie soos die mitologie wat meen dat hierdie samehang deur bonatuurlike magte verbreek word nie. Ons ontken die samehang as 
ons van God praat. Ons ontken dit ook as ons van onsself praat, want in hierdie samehang van wêreldgebeurtenisse is ons ' $2 k$ ', ons eie eksistensie, nie sigbaarder of meer bewysbaar as die handelende God nie. In die geloof word ons wel ook daarvan bewus dat die natuurwetenskaplike wêreldbeeld nie die ganse werklikheid van die wêreld en die mense omvat nie, maar die geloof bied nie' $n$ ander wêreldbeeld aan wat hierdie een op sy eie terrein korrigeer nie (Bultmann 1965a: 175).

Maar, sou ons kon vra, het God Hom dan nie self in die heilsfeite bewys, sodat ons daaroor objektiverend as handelinge van God kan praat nie? Geensins, antwoord Bultmann, want die sogenaamde heilsfeite is alleen deur die geloof waargeneem. Buite die geloof om is hulle nie sigbaar nie. Om hulle te erken, gaan nie die geloof vooraf sodat hulle die geloof onafhanklik moet begrond nie. Hulle begrond wel die geloof, maar dan as dinge wat deur die geloof self waargeneem word (Bultmann 1952a: 200; 1965a: 180). Wat God naamlik in Jesus Christus gedoen het, is nie ' $n$ historiese feit wat histories bewys kan word nie. Die historikus kan nie insien dat Jesus Christus vir die geloof is wat $\mathrm{Hy}$ is nie.

Ons het ook hier met 'n paradoks te doen. Jesus is 'n historiese persoon en die Christusgebeure is deel van die geskiedenis wat histories ondersoek kan word. En tog kan so 'n ondersoek dit nie tot sy eie maak dat Christus die eskatologiese gebeurtenis is nie (Bultmann 1965a: 185).

Daar is dikwels in antwoord en kritiek op Bultmann geargumenteer dat dit nie anders kan as dat van God en sy handelinge in mitologiese taal gepraat moet word nie. Hierop antwoord Bultmann dat alleen toegegee kan word dat die geloof die taal van die mite nodig het, as ons insien dat die mitologiese beelde en simbole na hulle betekenis gevra moet word. Hulle betekenis mag egter nie dan weer in mitologiese voorstellinge en terme uitgedruk word nie. Die ontmoeting met God wat net hier en nou in ruimte en tyd kan gebeur, kan nie oor gepraat word in simbole of beelde nie, maar slegs op analogiese wyse. So praat ons van God se handelinge soos van handelinge tussen mense. Ons noem Hom Vader en praat van sy liefde, genade, toorn ensovoorts (Bultmann 1948: 177v).

\subsubsection{God se openbaring}

Van God se openbaring soos die Nuwe Testament daarvan getuig, kan volgens Bultmann ook nie objektiverend as 'n algemene, tydlose waarheid gepraat word nie. Dit is ook nie 'n bonatuurlike meedeling 
van kennis of die oordra van 'n wêreldbeskouing nie (Bultmann 1960a: $30 \mathrm{v}$ ). Dit is altyd 'n kontingente gebeurtenis, 'n gebeurtenis wat deur God bewerkstellig word, 'n vrye daad van God. 'Seine Offenbarung ist Offenbarung nur in Actu und wird nie zur Offenbartheit' (Bultmann 1960b: 120v). God se openbaring is verder die openbaring van die lewe, en hierdie openbaring is niks anders nie, as die feit Jesus Christus (Bultmann 1960a: 18). Dit is fakties dus die heilsgebeure in Christus. Maar hoe is hierdie heilsgebeure sigbaar? Dit is nie as kosmiese gebeurtenis sigbaar nie, net so $\mathrm{min}$ as wat dit as innerlike ervaring sigbaar is. 'Nun, es ist offenbar als Verkündigung, im Wort' (Bultmann 1960a: 19). Dit is merkwaardig, sê Bultmann, dat juis die verkondiging ook openbaring genoem word. Wat hou dit in? Dit hou in dat Christus, wat die openbaring is, en die Woord eén is (Bultmann 1960a: 31). Hierdie Woord wat van God af kom, word byna uitsluitlik daardeur gekarakteriseer dat dit in menslike spreke na mense toe gekom het en kom. Dit is altyd Anrede en dit word alleen verstaan as die Anrede verstaan word, dit wil sê in eintlike sin gehoor word. Dit kan nie konstaterend waargeneem of vanuit 'n neutrale posisie verstaan word nie (Bultmann 1958a: 282). Dit is dus nie vir onbetrokke waarneming toeganklik nie. Ons word deur die Woord aangespreek, en ons verstaan daarvan is nie neutraal nie, maar ons antwoord op 'n roep (Bultmann 1965a: 179).

Die idee van die alomteenwoordige en almagtige God word net deur sy Woord wat hier en nou gespreek is, in my eksistensie tot werklikheid. Hieruit volg dat die Woord van God net op die oomblik wanneer dit gespreek word, dit is wat dit is. Dit is nie 'n tydlose uitspraak nie, maar 'n konkrete woord wat hier en nou tot mense gerig is. Dit is wel ewig, maar nie tydloos nie, omdat dit hier en nou gebeurende hede is. Dit is wel ook verbum externum, maar alleen wanneer dit my tref, en nie 'n wete (Wissen) is wat eens en vir altyd besit word nie (Bultmann 1965a: 184v). Dit is verstaanbare Woord, want as dit nie verstaanbaar was nie, sou dit nie Anrede kon wees nie. Dit werk egter nie magies nie en eis nie as dogma blinde navolging of die aanvaarding van absurditeite nie. Egte Anrede is slegs dit wat die mens homself leer verstaan, nie as teoretiese inligting oor die mens nie, '. . . sondern so, dass das Ereignis der Anrede ihm eine Situation des existentiellen SichVerstehens eröffnet, ihm eine Möglichkeit des Sich-Verstehens eröffnet, die in der Tat ergriffen werden muss' (Bultmann 1958a: 283). Op die oomblik dat hierdie Anrede tot die mens gerig word, lê die pad van die lewe en van die dood onderskeidelik vir hom oop. Deur die Anrede 
word hy geroep tot beslissing. Die hoor van die Anrede, naamlik die geloof, gee self die lewe. Die geloof is die beslissing vir die lewe in Eigentlichkeit en so open die Anrede vir die mens die moontlikheid om van homself, van sy vervallenheid, vry te word en eigentlich te eksisteer; en dit is die self-verstaan waartoe die Woord hom wil bring (Bultmann 1960a: 12).'Die Möglichkeit des Wortes verstanden zu werden, fällt zusammen mit der Möglichkeit für den Menschen, sich selbst zu verstehen' (Bultmann 1958d: 284). Dat die mens in die Woord, in die openbaring, homself leer verstaan, beteken dat hy sy nou, die oomblik, (die Jetzt), leer verstaan as 'n deur die verkondiging gekwalifiseerde. 'Denn das Sein im Augenblick ist sein eigentliches Sein' (Bultmann 1960a: 30). En omdat die openbaring is wat dit is in die oomblik van Anrede waarin dit in geloof gehoor en verstaan word, kan ons volgens Bultmann inderdaad ook sê dat die geloof self openbaring is, ' . . weil er nur in diesen Geschehen ist und sonst nicht ist' (Bultmann 1960a: 31).

\subsubsection{Die Christusgebeure}

Soos uit die voorafgaande reeds by verskeie geleenthede duidelik geword het, is daar by Bultmann geen twyfel dat die Nuwe Testament mitologies oor die Christusgebeure praat nie. Daar is vir hom egter met die Griekse of Hellenistiese kultusmites dié verskil dat Jesus Christus wat as Seun van God, as 'n preëksistente Godwese, 'n mitiese gestalte is, tegelyk 'n spesifieke historiese mens, Jesus van Nasaret is. So is die lotgevalle van sy persoon ook nie alleen 'n mitiese gebeure nie, maar tegelyk 'n menselot wat met die kruis eindig. Die historiese en mitiese is hier op eienaardige wyse ineengestrengel. Dit geld nie alleen die feit dat gestel word dat die historiese Jesus tegelyk die preëksistente Seun van God is nie, maar ook die kruis wat as historiese gebeurtenis staan naas die opstanding wat nie 'n historiese gebeurtenis is nie. Hierdie naasmekaar staan van die mitologiese en die historiese sowel as die teensprake in verband met Christus waarop reeds vroeër in hierdie opstel gewys is, laat Bultmann die vraag vra of die mitologiese spreke nie eenvoudig die intensie het om die betekenis van die historiese gestalte van Jesus en sy geskiedenis tot uitdrukking te bring nie. Hierop antwoord hy bevestigend deur byvoorbeeld daarop te wys dat uitsprake oor die preëksistensie en maagdelike geboorte se bedoeling is om die betekenis van die persoon van Jesus vir die geloof tot uitdrukking te bring. Die betekenis van Jesus kom nie aan die lig deur middel van 'n histories-vasstellende vraagstelling nie, en daarom moet ons daarvan afsien. Sy betekenis word wel duidelik deur wat God ons deur 
sy geskiedenis en kruis bekend wil maak (Bultmann 1948: 44v). Hierdie insig en oortuiging illustreer Bultmann dan veral aan die hand van die temas kruis en opstanding.

\subsubsection{Die kruis}

Is die kruis van Christus, vra Bultmann, net as 'n mitiese gebeurtenis te verstaan of kan dit ook as historiese gebeurtenis verstaan word, wel nie in die sin van die objektiveerbare wêreldhistoriese samehang nie, maar gesien in sy betekenis as heilsgebeurtenis? Die antwoord is dat ons die mitologiese interpretasie van die Nuwe Testament waarin offervoorstellings en 'n juridiese satisfaksieteorie met mekaar vermeng is, nie meer kan handhaaf nie. Hierdie mitologiese interpretasies sê buitendien ook nie wat dit moet sê nie. Dit sê hoogstens dat die mens se sonde hom vergewe is. Dit behoort ook nog te sê dat die gelowige deur die kruis bevry is van sonde as beheersende mag en derhalwe van die doen van sonde (Bultmann 1948: 45).

Wat is die betekenis van die kruis dan in werklikheid? Dit wil sê dat toe God vir Jesus laat kruisig het, $\mathrm{Hy}$ vir ons die kruis opgerig het. Om in die kruis van Christus te glo, beteken nie om ons oog te vestig op 'n mitiese gebeurtenis buite onsself en ons wêreld nie. Dit beteken dat ons sy kruis as ons eie moet oorneem en ons met Christus moet laat kruisig. Die kruis is nie 'n geïsoleerde gebeurtenis wat met Christus as mitiese persoon gebeur het nie, maar dit het wel in sy betekenis ' $n$ 'kosmiese' dimensie. Die beslissende, geskiedenisveranderende betekenis daarvan word daardeur tot uitdrukking gebring dat dit as die eskatologiese gebeurtenis geld. Dit is dus nie 'n gebeurtenis van die verlede waarop 'n mens terugkyk nie, maar 'n gebeurtenis wat altyd hede is. Dit is naamlik hede in die konkrete lewensuiting van die gelowige (Bultmann 1948: 46).

As heilsgebeurtenis is die kruis dus nie 'n mitiese nie, maar 'n historiese gebeurtenis wat sy oorsprong het in die kruisiging van Jesus van Nasaret. Hierdie kruis is na sy historiese betekenis die gerig oor die wêreld, die bevrydende gerig oor die mens. Die mitologiese spreke wil niks anders doen nie, as om hierdie betekenis tot uitdrukking te bring. Die historiese gebeurtenis van die kruis het deur sy eie betekenis 'n nuwe historiese situasie geskep. Die verkondiging van die kruis as heilsgebeurtenis vra naamlik van die hoorder of hy hierdie betekenis tot sy eie wil maak, of hy hom saam met Christus wil laat kruisig. Kan ons egter hierdie betekenis sommer so van die kruis aflees? Het die kruis hierdie betekenis omdat dit die kruis van Christus is? Indien dit 
wel die geval sou wees, sou ons eers oortuig moes word van die betekenis van die historiese Jesus. So was dit wel met die eerste Christene wat Hom beleef het. Vir ons is hierdie situasie nie reproduseerbaar nie en daarom kan ons die betekenis van die kruis nie daaruit aflei nie. Christus word dan ook nie in die Nuwe Testament verkondig as die gekruisigde met wie daar 'n vooragaande verbintenis was of moes wees nie, maar as die gekruisigde wat tegelyk die opgestane is. Kruis en opstanding hoort tot 'n eenheid saam (Bultmann 1948: 47).

\subsubsection{Die opstanding}

Is die opstanding van Christus nie gewoon 'n mitiese gebeurtenis nie? 'n Historiese gebeurtenis wat na sy betekenis verstaan moet word, is dit volgens Bultmann in elk geval nie. Vir hom is die vraag dus of dit iets anders kan wees as die uitdrukking van die betekenis van sy kruis. Dit is nie so dat die kruis van Christus die ondergang in die dood beteken en die opstanding die tot-niet-maak van die dood is nie. In so 'n geval sou die opstanding as verifiërende mirakel gesien moes word. Hoewel dit in sommige gevalle in die Nuwe Testament inderdaad so gesien word (Luk 24: 39-43; Hand 17: 31 en in 'n sekere sin ook 1 Kor 15: 3-8), het ons hier met latere vormings te doen. Paulus se bedoeling was in elke geval nie om die opstanding as objektiewe historiese feit geloofwaardig te maak nie, maar slegs om te sê dat hy op dieselfde wyse as die vroegste gemeente Jesus as die opgestane verkondig. Die getuies waarna Paulus verwys, is getuies vir die Pauliniese evangelie en nie vir die feit van die opstanding nie (Bultmann 1948: 48).

Die opstanding van Christus kan om twee redes nie 'n verifiërende mirakel wees nie. Enersyds is dit as mitiese gebeurtenis, naamlik terugkeer van 'n gestorwene na die lewe in hierdie wêreld, ongeloofwaardig. Andersyds kon dit ten spyte van al die baie getuies, eenvoudig nog nie as 'n historiese feit vasgestel word nie. Die opstanding is voorwerp van geloof omdat dit baie meer sê as die terugkeer van 'n dooie na die lewe, omdat dit 'n eskatologiese gebeurtenis is (Bultmann 1948: 49). Dit is dus geen mitiese gebeurtenis wat die betekenis van die kruis geloofwaardig kan maak nie, maar word sonder meer geglo as die betekenis van die kruis. 'Ja der Auferstehungsglaube ist nichts anderes als der Glaube an das Kreuz als Heilsereignis, an das Kreuz als Kreuz Christi' (Bultmann 1948: 50). Die kruis is ook nie heilsgebeurtenis omdat dit die kruis van Christus is nie, dit is die kruis van Christus omdat dit die heilsgebeurtenis is. Maar hoe weet ons dat dit die kruis van Christus is, die eskatologiese gebeurtenis? Ons weet dit omdat dit 
so verkondig word. Net dit. Christus, die gekruisigde en opgestane, ontmoet ons in die woorde van die verkondiging, nêrens anders nie. Juis die geloof in hierdie verkondiging is die ware paasgeloof. Die verkondiging vra van ons geloof en dan só dat daardeur vir ons die moontlikheid van die verstaan van onsself geopen word. Die paasgebeurtenis, vir sover dit as historiese gebeurtenis naas die kruis genoem kan word, is niks anders as die ontstaan van die geloof in die opgestane nie. 'Das Osterereignis als Auferstehung Christi ist kein historisches Ereignis; als historisches Ereignis ist nur der Osterglaube der ersten Jünger fassbar' (Bultmann 1948: 51). Die paasgeloof van die eerste dissipels is egter nie ' $n$ feit op grond waarvan ons glo nie; dit behoort self tot die eskatologiese gebeure, wat die voorwerp van die geloof is. Hierdie paasgeloof vra van die mens dat hy hom as saamgekruisigde en daarby as saamopgewekte sal verstaan. In die geklank van die woord van die verkondiging word kruis en opstanding hede, gebeur die eskatologiese Jetzt, die gerig of die lewe. Wie die Woord (gelowig) verneem het, het in ontmoeting met die opgestane getree, glo in die opgestane. 'Im gepredigten Wort und nur in ihm begegnet der Auferstandene' (Bultmann 1948: 51). En vir die mens geld die volgende: 'Hört er es als das zu ihm gesprochene, ihm den Tod und dadurch das Leben zusprechende Wort, so glaubt er an den Auferstandenen' (Bultmann 1968: 305v).

\subsubsection{Die eskatologie}

Ons het reeds onder 3.1 hierbo gesien dat Bultmann van oortuiging is dat dit reeds in die Nuwe Testament blyk dat die vroegste kerk nie oral en altyd die mitologiese eskatologiese verwagting bly handhaaf het of kon bly handhaaf nie. Ons het ook gesien dat hy reeds by Paulus ' $n$ klemverskuiwing, 'n gedeeltelike ontmitologisering van die eskatologie bemerk en dat dit by Johannes radikaal deurgevoer is. Hoewel hy ook meen dat Jesus in sy eskatologiese prediking voluit van mitologiese denkbeelde en taal gebruik gemaak het, is hy ook van oordeel dat daarin ' $n$ dieper betekenis lê as wat 'n mens op die oog af daaruit sou kon aflei. Die diepere betekenis van Jesus se mitologiese prediking sou dan wees: oop wees vir God se toekoms wat vir elkeen van ons wag; gereed wees vir hierdie toekoms wat so onverwags soos 'n dief in die nag sal kom; gereed wees omdat hierdie toekoms 'n gerig sal wees oor die mense wat hulle aan hierdie wêreld verbind het en nie vry is nie, nie oop is vir God se toekoms nie (Bultmann 1965a: 154). Hierdie interpretasie van Jesus se eskatologiese prediking is duidelik ook 
eksistensiale interpretasie deurdat dit vra na die eksistensiële implikasies wat dit vir die mens in sy verhouding tot God as die toekomstige het.

Daar bestaan egter nie twyfel nie, dat Bultmann hom veral met die Johannese eskatologiese denke vereenselwig, hoewel hy Paulus nie buite rekening laat nie. Hy is dan ook van oordeel dat die oplossing van die Nuwe-Testamentiese verstaan van die geskiedenis van Jesus by beide Paulus en Johannes gevind kan word. Beide Paulus en Johannes het ingesien dat Christus '. . . das stets jeweils gegenwärtige oder stets jeweils gegenwärtig werdende eschatologische Ereignis ist' (Bultmann 1960c: 105). Dit beteken dat veral by Johannes die letzt eskatologiese karakter verkry deur die ontmoeting met Christus of met die Woord wat Hom verkondig, terwyl in die ontmoeting met Hom die wêreld en sy geskiedenis (vir die gelowige) tot hulle einde kom en die gelowige as nuwe skepsel entweltlicht is (Bultmann 1960c: 105). Soos ons reeds vroeër gesien het, beteken dit in Johannese terme vir Bultmann (1965ג: 155) dat die gelowige 'schon jetzt das ewige Leben' het. In werklikheid het die eskatologiese eksistensie vir die mense dáárdeur 'n moontlikheid geword dat God gehandel het en aan die wêreld as 'hierdie wêreld' 'n einde gemaak het, deurdat $\mathrm{Hy}$ die mens self nuut gemaak het (Bultmann 1948: 42).

Die paradoks van geskiedenis en eskatologie bestaan vir Bultmann daarin dat die eskatologiese gebeure in die geskiedenis plaasgevind het en oral weer in die prediking plaasvind. Hieruit volg dat die eskatologie in sy ware Christelike sin nie die toekomstige einde van die geskiedenis is nie, maar dat die geskiedenis deur die eskatologie binnegedring is. Van nou af kan die geskiedenis nie langer as heilsgeskiedenis nie, maar slegs as profane geskiedenis verstaan word. Die geskiedenis van die mens as persoon kan ook nie meer as funksie van die wêreldgeskiedenis verstaan word nie; dit lê nou anderkant die wêreldgeskiedenis (Bultmann 1960c: 106). Tog is die gelowige ook nog deel van die wêreldgeskiedenis en daarom is sy eksistensie as gelowige ook 'n paradoks. 'Die paradoxie der christlichen Existenz ist die, dass der Glaubende der Welt entnommen ist, als gleichsam Entweltlichter existiert, und dass er zugleich innerhalb der Welt, innerhalb seiner Geschichtlichkeit bleibt' (Bultmann 1964: 181). Maar historiese syn is syn uit die toekoms en ook die gelowige eksisteer uit die toekoms. Sy nuwe eksistensie, sy vryheid, kan nooit 'n besit of eienskap word nie. Dit kan nie tot ' $\mathrm{n}$ feit van die verlede word nie, omdat dit steeds as gebeurtenis 'n werklikheid is en moet wees. Dit moet telkens weer en weer in die 
beslissing van elke oomblik van die lewe aangegryp word. Die toekoms bied die mens steeds sy vryheid as geskenk aan, en die geloof is die krag waarmee dit telkens aangegryp moet word. So word hy vry van die verlede en leef hy toekomstig, naamlik eskatologies. 'Jeder Augenblick hat die Möglichkeit, ein eschatologischer Augenblick zu sein, und im christlichen Glauben ist diese Möglichkeit verwirklicht' (Bultmann 1964: 183).

Wat lewer die ontmitologisering van die mitologiese eskatologie van die Nuwe Testament uiteindelik vir ons op? Bultmann se antwoord hierop is: 'Der durch die Entmythologisierung freigelegte Sinn der mythologischen Hoffnungsbilder aber ist der, dass sie von der Zukunft Gottes reden als von der Erfüllung des menschlichen Lebens' (Bultmann 1960d: 90).

\section{ENKELE EVALUERENDE OPMERKINGS}

Die leser sal begryp dat dit binne die bestek van hierdie opstel onmoontlik is om ' $n$ grondige en indringende evaluering te doen, en daarby 'n evaluering wat aan Bultmann sal laat reg geskied. Dit is iets wat miskien in 'n volgende opstel onderneem moet word, hoewel ek terdeë bewus is van die omvangrykheid en gewigtigheid van so 'n onderneming. Tog wil ek dit waag om 'n paar opmerkings oor die saak te maak.

Ek wil begin deur te stel dat Bultmann se volgehoue pogings om die Nuwe Testament, soos dit ook uit hierdie ondersoek duidelik geblyk het, vir die mens van vandag steeds geloofwaardig en verstaanbaar te maak, positief gewaardeer moet word. Dit is wel waar dat sommige van sy uitsprake vir die oor en die gemoed wat gewoond is aan tradisionele teologiese of dogmatiese paradigmas skokkend klink, maar dan moet 'n mens jou afvra of dit nie juis nodig is nie.

'n Mens kan, soos so dikwels gebeur het, Bultmann se definisie van ' $n$ mite as te eensydig en simplisties kritiseer en met hom daaroor verskil, maar ' $n$ mens kan nie ontken dat daar inderdaad ' $n$ probleem is nie. Wie so eerlik wil wees as Bultmann, sal moet erken dat 'n mens eenvoudig nie meer die wêreldbeeld van die Bybel op die moderne mens kan afdwing nie. Dit beteken tog beslis nie dat die moderne mens en sy wêreldbeeld die maatstaf word vir die saak waarom dit in die Bybel gaan nie. Bultmann wil juis ook nie dat die Bybelse verkondiging sal word tot die verkondiging van die moderne wêreldbeeld nie. Dit is nie 'n wêreldbeeld wat verkondig moet word nie, maar die evangelie. Dat die verkondiging van die Nuwe Testament egter geklee is in 
begrippe, taal en terme wat eie was aan die wêreldbeeld van daardie tyd en omgewing, kan nie ontken word nie.

Wat bly anders vir ons oor as om die betrokke uitsprake of verkondiging van die Nuwe Testament te interpreteer na die saak waarom dit gaan? As ons daarmee objektiverend sou omgaan soos die natuur- of geskiedswetenskap, dan moet ons aanvaar dat relativisme nie net voor die deur sal kom staan nie, maar hom ook sal kom tuismaak, soos inderdaad by die historisme gebeur het. Van so 'n relativisme en 'n uiteindelike quiëtisme of nihilisme wil Bultmann juis die Bybel vrywaar. Dit moet immers as werkwaardig, en miskien selfs verstommend, aangemerk word dat Bultmann wat as 'n historikus self so indringend histories-krities met die Nuwe Testament omgegaan het, soveel gedoen het om die saak van die Nuwe Testament vir die geloof vry te stel. Dit moet daaraan toegeskryf word dat hy juis op grond van sy historiese vraagstelling ingesien het dat God en sy openbaring nie onderwerp kan word aan objektiverende en verifiërende kenteorieë en programme nie. Hy het ingesien dat God en sy openbaring nie uitgelewer kan word aan die resultate van hierdie denke nie, omdat God en sy openbaring eenvoudig nie 'n wêreldfenomeen is nie. God is die gans andere, die transendente wat nie vir objektiewe waarneming toeganklik of daardeur bewysbaar is nie.

Aan hoeveel kritiek Bultmann se ontmitologiseringsprogram ook al tot hiertoe onderwerp is, feit is dat baie van sy insigte in hierdie verband algaande in die teologie en dan veral die Bybelse teologie neerslag gevind het. Vandag word in al meer kringe, soms wel met bepaalde reserwes, aanvaar dat ons met 'mitologie' in die Skrif te doen het en dat dit noodsaaklik is om dit vir die hedendaagse mens te interpreteer. Die volgende twee opmerkings illustreer hierdie feit: 'So ist es richtig, zu sagen, dass das Neue Testament selbst die Aufgabe der Entmythologisierung stellt' (Luz 1966: 367). 'Wir - zumal wir heutige haben wohl Mühe, mit Mythen umzugehen. Darum bleibt Entmythologisierung unsere Aufgabe' (Schelkle 1985: 265). Al sou ons ook saamstem dat 'n mens nie anders as mities oor God en sy handelinge, en dan bepaald sy handeling in Jesus Christus kan praat nie, neem dit nog nie weg dat ons dit sal moet interpreteer, verstaanbaar sal moet maak nie. Bultmann was hom altyd terdeë bewus van hierdie mitologiese 'res', hierdie feit dat God in Jesus Christus gehandel het en ons so extra nos aanspreek en nou nog aanspreek. Hy kon en hy wou dit ook nie elimineer nie; hy het bloot die noodsaaklikheid gestel dat ons dit moet interpreteer. 
Die eksistensiale interpretasie waarvan Bultmann hom bedien het en wat, soos bekend, ook sy eie maat aan kritiek ontvang het, hoef seker nie beskou te word as die absolute vertrekpunt of die enigste antwoord vir ons probleem nie. Wat egter nie weggeredeneer kan word nie, is dat dit 'n uiters bruikbare hermeneutiese sleutel is om die Bybeltekste na hulle bedoeling te vra. Wat wil die Woord van God anders as om die mens in sy konkrete eksistensie aan te spreek? Waarop het dit anders betrekking as op die eksistensiële verhouding waarin die mens tot God staan? Watter ander doel het dit as om die mens tot 'n nuwe verstaan van sy eksistensie, tot ' $n$ nuwe selfverstaan te bring?

Om die eksistensiale interpretasie verdag te mak of af te skiet omdat dit die eksegese aan 'n filosofie sou uitverkoop, is inderdaad om die oë te sluit vir' $n$ onontkenbare feit. Hierdie feit waarop Bultmann juis ook ons aandag gevestig het, is dat die teologie eintlik nog nooit bedryf is sonder dat daar in 'n sekere mate van filosofiese begripsmateriaal gebruik gemaak is nie. ' $n$ Mens hoef maar slegs na die geskiedenis van Bybelse hermeneutiek te kyk, om te sien hoedat hierdie feit daardeur bevestig word. Elke nuwe rigting in Bybelse hermeneutiek is naamlik voorafgegaan en beïnvloed deur een of ander nuwe rigting in die filosofiese denke. Voeg hierby die groot skaal waarop in eksegetiese metodologie gebruik gemaak is en word van die teks- en interpretasieteorieë wat op die gebied van die algemene taal- en literatuurwetenskap ontwikkel is.

Bultmann gee self toe dat daar nie so iets is as ' $n$ ideale of regte filosofie nie (Bultmann 1965a: 169). Soos reeds hierbo gemeld, beskou hy die filosofie van Heidegger slegs as 'regte' filosofie omdat dit spesifiek konsentreer op die menslike eksistensie, die saak waarop die verkondiging van die Nuwe Testament hom rig. Die bewering of vrees dat die vraag na die moontlikhede vir selfverstaan wat daar in die Nuwe Testament tot uitdrukking gebring word, die eksegese maak tot 'n mensgesentreerde onderneming, het nie grond nie. Dit gaan nie hier oor beskouinge wat die mens oor homself het wat op die Bybelse boodskap afgedruk word nie, maar juis om die nuwe moontlikhede vir selfverstaan wat die Bybel vir die mens open. Dunn (1977: 327) het die saak raakgevat met die volgende stelling:

The problem of 'self-understanding' is often misunderstood. It does not simply mean man's conscious understanding of himself, but his grasp of the possibilities of being, in the context of his 'world'. It concerns, therefore, his way of reacting to life or to reality or to God and not merely his opinions about himself. 
Die winste wat deur die eksistensiale interpretasie van Bultmann en van ander op sy voetspoor opgelewer is, is onberekenbaar. Dit het ons minstens geleer dat Christen-wees of gelowig-wees nie bestaan uit die vir-waar-hou van algemene waarhede of die aanhang van leerstukke nie. Dit het ons geleer dat gelowig-wees beteken om hier en nou en telkens weer in 'n lewende eksistensiële verhouding met God te tree; om hier en nou en telkens weer deur die hoor van God se Anrede afskeid te neem van ons uneigentliche verlede, ons vervallenheid aan die Verfügbare, en in die hede inderdaad eigentlich, dit wil sê uit die Unverfügbare (God) te eksisteer; om hier en nou en telkens weer vanuit God se toekoms verantwoordelikheid vir die hede te aanvaar; om oop te wees vir God se toekoms deur sy eskatologiese bevrydingsdaad hier en nou tot ons eie te maak en eskatologies te eksisteer.

Ek sluit af met die woorde van Bornkamm na Bultmann se afsterwe op 30 Julie 1976:

Doch würde die Wissenschaft des Neuen Testamentes von Bultmann nicht nur Abschied nehmen, sondern ihm den Abschied geben, wenn sich beruhigt wieder auf das sturmfreie Feld blosser Tatsachenforschung zurückzöge. Gerade der herausfordernde Anruf seiner Theologie darf nicht verstummen, und abenso wenig darf die Bereitschaft aufhören, ihre Einsichten und Anstösse aufzunehmen und für die Interpretation des Neuen Testamentes fruchtbar zu machen (Bornkamm 1977: 242).

Hierdie opstel word met waardering en in dankbare erkenning opgedra aan ' $n$ teoloog, filosoof en opvoedkundige van formaat, iemand wat nie alleen in die breëre Suid-Afrikaanse konteks en op kerklike gebied diep spore getrap het nie, maar op my persoonlik 'n blywende en onuitwisbare indruk gemaak het, $\mathrm{CH}$ Rautenbach. Ek doen dit met die vertroue dat hierdie opstel die grootheid van sy persoon en die rykdom van sy nalatenskap waardig sal wees. Dit was en is ' $n$ voorreg om hom te ken en sy geweldige insig, omvangryke kennis en skerp intellek te ervaar.

\section{Literatuurverwysings}

BORNKAMM, G 1977. In memoriam Rudolf Bultmann. NTS 23, 235-242.

BULTMANN, R 1948. Neues Testament und Mythologie: Das Problem der Entmythologisierung der neutestamentlichen Verkündigung, in Bartsch, HW (Hrsg), Kerygma und Mythos: Ein theologisches Gespräch, 15-53. Hamburg: Rein \& Heidricher-evangelischer Verlag (ThF1.) 
BULTMANN, R [1933] 1958. Glauben und Verstehen: Gesammelte Aufsätze I. 3. Aufl. Tübingen: Mohr.

BULTMANN, R 1952. Glauben und Verstehen: Gesammelte Aufsätze II. Tübingen: Mohr.

BULTMANN, R 1960. Glauben und Verstehen: Gesammelte Aufsätze III. Tübingen: Mohr.

BULTMANN, R 1965. Glauben und Verstehen: Gesammelte Aufsätze IV. Tübingen: Mohr.

BULTMANN, R 1952a. Zum Problem der Entmythologisierung, in Bartsch, HW (Hrsg),

Kerygma und Mythos II. Band: Diskussionen und Stimmen zum Problem der Entmythologisierung, 179-195. Hamburg-Volksdorf: Herbert Reich-evangelischer Verlag. (ThF2.)

BULTMANN, R 1952b. Das problem der Hermeneutik, in Bultmann 1952: 211-235.

BULTMANN, R 1954. Zur Frage der Entmythologisierung: Antwort an Karl Jaspers, in Bartsch, HW (Hrsg), Kerygma und Mythos, III. Band: Das Gespräch mit der Philosophie, 49-59. Hamburg-Volksdorf: Herbert Reich-evangelischer Verlag (ThF5.)

BULTMANN, R 1958a. Die Eschatologie des Johannesevangeliums, in Bultmann 1958: 134-152.

BULTMANN, R 1958b. Welchen Sinn hat es, von Gott zu reden?, in Bultmann 1958: 26-37.

BULTMANN, R 1958c. Die Bedeutung der 'dialektischen Theologie' für die neutestamentliche Wissenschaft, in Bultmann 1958: 114-133.

BULTMANN, R 1958d. Der Begriff des Wortes Gottes im Neuen Testament, in Bultmann 1958: 268-293.

BULTMANN, R 1960a. Der Begriff der Offenbarung im Neuen Testament, in Bultmann 1960: $1-34$.

BULTMANN, R 1960b. Wissenschaft und Existenz, in Bultmann 1960: 107-121.

BULTMANN, R 1960c. Geschichte und Eschatologie im Neuen Testament, in Bultmann 1960: 91-106.

BULTMANN, R 1960d. Die christliche Hoffnung und das Problem der Entmythologisierung, in Bultmann 1960: 81-90.

BULTMANN, R 1964. Geschichte und Eschatologie. 2. Aufl. Tübingen: Mohr.

BULTMANN, R 1965a. Jesus Christus und die Mythologie, in Bultmann 1965: 141-189.

BULTMANN, R 1965b. Zum Problem der Entmythologisierung, in Bultmann 1965: 128-137.

BULTMANN, R 1967. Jesus und Paulus, in Dinkler, E (Hrsg), Exegitica: Aufsätze zur Erforschung des Neuen Testaments, 210-229. Tübingen: Mohr.

BULTMANN, R 1968. Theologie des Neuen Testaments. 6. Aufl. Tübingen: Mohr.

DUNN, JDG 1977. Demythologizing - The problem of myth in the New Testament, in Marshall IH (ed), New Testament interpretation: Essays in principles and methods, 285-307. Exeter: Paternoster.

HÜBNER, H 1985. Rückblick auf das Bultmann-Gedenkjahr 1984. ThLZ 110, 641-652.

LUZ, U 1966. Entmythologisierung als Aufgabe der Christologie. EvTh 26, 349-368.

SCHELKLE, KH 1985. Entmythologisierung in existentialer Interpretation. ThQ 165, $257-266$.

SCHMITHALS, W 1966. The Theologie Rudolf Bultmanns: Ein Einführung. Tübingen: Mohr. 